\title{
PROBLEM-BASED LEARNING: EFFECTS ON ACADEMIC PERFORMANCE AND PERCEPTIONS OF ENGINEERING STUDENTS IN COMPUTER SCIENCES
}

\author{
Danilo Amaya Chávez ${ }^{1}$ (D), Vanesa-María Gámiz-Sánchez ${ }^{2}$ (i), Antonio Cañas Vargas ${ }^{2}$ (D) \\ ${ }^{1}$ Universidad de las Ciencias Informáticas (Cuba) \\ ${ }^{2}$ University of Granada (Spain) \\ dach@uci.cu,vanesa@ugr.es,acanas@ugr.es
}

Received March 2020

Accepted July 2020

\section{Abstract}

In the present article we analyse the impact of problem-based learning (PBL) on learning and perceptions in first-year students undertaking Engineering in Computer Sciences. The module designed took a number of advanced theories of PBL and its application within the Engineering profession. Mixed methods were used to enable data from qualitative and quantitative instruments to be obtained. A quasi-experimental design was specified, employing non-probabilistic sampling, with a control $(N=40)$ and experimental group $(N=39)$. In comparing PBL with traditional methods, the results reveal statistically significant differences in aspects such as academic performance. Teamwork, oral communication, written communication and students' perceptions of the learning experience were also all favoured. Nonetheless, lack of adequate team dynamics in previous learning experiences and reluctance to change traditional teaching approaches, could compromise the viability of that proposed.

Keywords - Problem-based learning, Teamwork, Education in engineering, Higher education, Academic performance.

\section{To cite this article:}

Amaya Chávez, D., Gámiz-Sánchez, V.M., \& Cañas Vargas, A. (2020). Problem-based learning: Effects on academic performance and perceptions of engineering students in computer sciences. Journal of Technology and Science Education, 10(2), 306-328. https://doi.org/10.3926/jotse.969

\section{Introduction}

Study programs pertaining to the subjects of Sciences, Technology, Engineering, Arts and Mathematics (STEAM subjects) are crucial due to their close link with economic, scientific and technological development. Indeed, such development comes from the introduction and assimilation of advances in these disciplines within a given country or region (Kumar, 2017). To this effect, teacher training in higher education institutions should be seen as vital. On the one hand, it is relevant for the development of specific skills which provide a solid theoretical and conceptual basis from which advances can emerge. On the other hand, it develops generic skills which are considered to be the most important for educators, graduates and employers. Within the latter set of skills, teamwork, oral and written communication, problem solving and self-directed learning particularly stand out (Passow, 2012; Warnock \& 
Mohammadi-Aragh, 2015). One option for successfully installing these skills is to bring students closer to the real world. Engineers design and propose solutions for professional problems based on the similarity or analogy of these problems with already resolved cases from their practical experience. Thus, the more students are faced with real-life situations, the better prepared they will be when their job position requires them to put the professional skills they have acquired during their degree studies into practice (Kaplan \& Vinck, 2013).

Adoption of these active methods by universities demands the active participation of students. This generates meaningful and enduring learning, and enables content to be applied in real heterogenous contexts. One of these methods is PBL (Problem-Based Learning). Through PBL, various authors reveal that learners improve their understanding of content, strengthen self-directed learning, develop active learning, and broaden their inter-disciplinary perspective and general knowledge (Gijbels, Dochy, Van den Bossche \& Segers, 2005; Leary, Walker, Shelton \& Fitt, 2013; Kim, 2017). In the same way, it is proposed that PBL contributes to the development of project management, collaboration, teamwork, conflict resolution and communication skills (McLoone, Lawlor \& Meehan, 2016; Macho-Stadler \& Elejalde-García, 2013). In engineering, the majority of research related with the use of this method has sought to analyse its influence on the development of student's critical thinking, training and development of professional skills, conceptual understanding of learning content and the obtainment of meaningful gains in the learning of content. All of this is manifested as improved academic performance (Fernández \& Duarte, 2013; Yadav, Sumedi, Lundeberg \& Bunting, 2011; Rodríguez \& Fernández-Batanero, 2017; amongst others).

In this sense, relevant learning experiences of the aspects described above were developed. It is highlighted that the training model for the Cuban system of higher education is based on objectives rather than competencies. Given this situation, the need to promote student-centred curricular content through which students can develop professional competencies for their later professional practice has been outlined in the Documento Base para el diseño de los Planes de Estudio E, the basic paper for the design of study plans (Ministry of Higher Education [MES], 2016). Recently, many degree courses have conducted a process of curricular re-design to address this, despite the fact that its assimilation is still considered to be in the adaptation and development stage.

Within the degree of Engineering in Computer Sciences, a number of general and short-term goals have been established which address a skillset that must be acquired by students as they progress through the course. In contrast, the methodologies that govern teaching and learning processes in different disciplines and subjects are traditional in nature, with lecturing and independent work approaches predominating. No projection towards the use of active methods is seen, despite the fact that their potential for skills training and development has been proven (Fernández-March, 2006).

In agreement with that presented above, the ability of active methodologies to assist the development of required skills moves authors to consider that the implementation of PBL, as an active teaching-learning method that aligns with degree aims. It should, therefore, provide greater solidity to learning content, with this being reflected in the improved academic performance of students. At the same time, this will positively influence perceptions of teamwork and attitudes regarding the employment of this type of method. The present article pursues three main objectives which are presented next:

1. Analyse the effects provoked by the application of a PBL approach on the academic performance of first-year students undertaking an Engineering in Computer Sciences degree.

2. Examine the attitudes and perceptions of students regarding their experiences of PBL.

3. Analyse student perceptions with respect to the influence of PBL on their ability to work in a team. 


\section{Theoretical Framework}

\subsection{Problem-Based Learning. Implications for Learning}

PBL is an instructional student-centred model in which knowledge is acquired through the identification of gaps between the level of knowledge possessed by students and that required to resolve a given problem (Barrows, 1986). In this way, non-structured problems are presented. In response to this, self-directed learning is developed, alongside the combination of both individual and collaborative learning activities, under the tutelage of the teacher who acts to facilitate this process (Savery, 2015). This didactic technique, considered to be an active methodology, has been employed as a work strategy throughout entire academic courses or to address specific topics within the different disciplines of a study plan (Fernández \& Duarte, 2013). A systematic review performed in health sciences by Yew and Goh (2016) confirmed that PBL was effective for knowledge retainment over the long-term and knowledge application in practice.

PBL use on engineering courses has demonstrated notable advantages for motivating and involving students in authentic situations of real work, improving meta-cognition, favouring problem solving, and developing critical thinking and professional skills (Othman, Mat-Daud, Ewon, Mohd-Salleh, Omar, Abd-Baser et al., 2017; Schmidt, 1993). Rodríguez and Fernández-Batanero (2016) carried out a review of the PBL methods applied in engineering courses. They noted that "for engineering disciplines, it is necessary to present real-world problems or those as close as possible to real situations, associating this with applications in the professional context in which the student will practice in the future" (p.17). In this vein, a number of empirical studies report that PBL has been used to promote the acquisition of learning content (Lachiver, Dalle, Boutin, Clavet \& Dirand, 2002; Polanco, Calderón \& Delgado, 2004; Dochy, Segers, Van den Bossche \& Gijbels, 2003; Said, Mahamd-Adikan, Mekhilef \& Abd-Rahim 2005; Morss \& Billiar, 2016), improve conceptual understanding and perceptions of learning (Yadav et.al., 2011; Hande, Mohammed \& Komattil, 2015), and improve academic performance (Dagyar \&Demirel, 2015; Dalfaro, Del Valle \& Aguilar, 2017, Rodríguez \& Fernández-Batanero, 2016, 2017).

\subsection{PBL Models and their Application in Engineering}

PBL was conceived in the Faculty of Medicine at McMaster University in Canada by Barrows (1986) who defined the classic or original model. Following this, Yih-Chyn and Huijser (2017) re-affirmed the characteristics of the model. These results were presented in an unpublished text, written before the death of the author on the $25^{\text {th }}$ of March 2011. These characteristics provide a theoretical benchmark and diverse models in different study disciplines have taken them into consideration. Barrows discussed the authenticity of PBL in that it is developed around real problems, student-centred, and develops problem-solving skills, self-directed learning, self-evaluation, co-evaluation and collaborative learning in small-group situations. All of this occurs in the presence of expert teachers.

Following this, the classic model has been adopted by similar schools (Maastricht, Newcastle, Roskilde and Linköping, amongst others) and introduced into other branches such as social sciences, law and engineering. The model is introduced through more specific models developed within the different subjects and study disciplines (Schmidt, 1993; Hung, 2006; Kolmos, Fink \& Krogh, 2004; Koschmann \& Stahl, 1998; Savin-Baden, 2007, 2014; amongst others). The stages through which the process of PBL is developed depends on the characteristics of each degree course and academic discipline. In engineering, the stages that are normally adopted are those of preparation, problem analysis, issue identification, problem solving, conclusions and report (Graaff \& Kolmos, 2007). Within the branch of engineering, models emerge such as that developed in the Polytechnic School of Singapore, known as "One-day-one-problem". This is characterised by its modular arrangement around problems and is philosophically alligned with constructivist learning. It functions within a more structured setting in comparison to conventional PBL, encouraging students to build confidence, alongside their teamwork and self-directed learning skills (Wang \& Fong, 2006; Yew \& O'Grady, 2012). The model proposed by the Technological University of Malaysia (Mohd-Yusof, Hassim, \& Azila, 2004; Said et al., 2005; Mohd-Yusof, 
Sadikin, Phang, \& Abdul-Aziz, 2016) is distinguished by a cooperative PBL process based on the course and is instituted through an academic approach. Iron Range Engineering used in Minnesota, the United States (Iron Range Resources, 2010; Allendoerfer, Bates, Karlin, Ulseth, \& Ewert, 2015; Bates, \& Ulseth , 2013), considered as an adaptation of the Aalborg model (Kolmos et al., 2004), includes the use of actual industry projects with an explicit focus on the technical, professional and creative development of students. The model applied at the University of Minho, Portugal (Moreira, Mesquita, \& Hattum-Janssen, 2011; Alves, Sousa, Fernandes, Cardoso, Carvalho, Figueiredo et al., 2016) proposes an inter-disciplinary project focused on the development of technical and transversal skills. Finally, the model applied within the Engineering School of Mondragon University (Spain) aims to produce graduates with technical and transversal skills who are ready to work in industry (Arana-Arexolaleiba, \& Zubizarreta, 2015; Guerra, Ulseth \& Kolmos, 2017).

\begin{tabular}{|c|c|c|c|c|}
\hline $\begin{array}{c}\text { Type } \\
\text { (model stages) }\end{array}$ & Modality & Themes & Resources & Actions \\
\hline $\begin{array}{l}\text { Introductory } \\
\text { lecture }\end{array}$ & Face-to-face & $\begin{array}{l}\text { PBL methodology, } \\
\text { teamwork indicators, } \\
\text { guidelines for the } \\
\text { presentation and } \\
\text { delivery of responses, } \\
\text { familiarization with } \\
\text { working on Moodle } \\
\text { and rubrics }\end{array}$ & $\begin{array}{l}\text { Print PBL materials, } \\
\text { teamwork guides, } \\
\text { course platform, } \\
\text { videos, electronic } \\
\text { presentations (Ppt or } \\
\text { Prezi) }\end{array}$ & $\begin{array}{l}\text { Team formation and } \\
\text { delegation of roles. } \\
\text { Application of the initial } \\
\text { rubric about teamworking }\end{array}$ \\
\hline $\begin{array}{l}\text { Lecture } \\
\text { (Recognition) }\end{array}$ & Face-to-face & $\begin{array}{l}\text { Notions about graphs, } \\
\text { Handshaking lemma, } \\
\text { graphs and algebra of } \\
\text { sets, connectedness, } \\
\text { special graphs }\end{array}$ & $\begin{array}{l}\text { Lesson on the topic } \\
\text { being considered, } \\
\text { videos, electronic } \\
\text { presentation (Ppt or } \\
\text { Prezi), Moodle course } \\
\text { platform }\end{array}$ & $\begin{array}{l}\text { Problem analysis. } \\
\text { Brainstorming to identify } \\
\text { learning problems and form } \\
\text { hypotheses. Action plan } \\
\text { development to find solutions. }\end{array}$ \\
\hline $\begin{array}{l}\text { Practical class } \\
\text { (research) }\end{array}$ & $\begin{array}{l}\text { Blended (partly } \\
\text { face-to-face) }\end{array}$ & $\begin{array}{l}\text { Learning situations } \\
\text { referred to the } \\
\text { content under study }\end{array}$ & $\begin{array}{l}\text { Resources in various } \\
\text { formats and made } \\
\text { available in the } \\
\text { platform (videos, } \\
\text { podcast, e-Textbook, } \\
\text { direct web access). } \\
\text { Social network groups. } \\
\text { Discussion forums } \\
\text { and chats }\end{array}$ & $\begin{array}{l}\text { Search of information } \\
\text { necessary for solving identified } \\
\text { learning tasks (self-directed } \\
\text { learning). Collaboration with } \\
\text { peers, exchange of } \\
\text { information. Sharing of } \\
\text { results. Formulation of } \\
\text { possible solutions. Preparation } \\
\text { of the report of the results. }\end{array}$ \\
\hline $\begin{array}{l}\text { Practical class } \\
\text { (report) }\end{array}$ & Face-to-face & $\begin{array}{l}\text { Learning situations } \\
\text { referred to the } \\
\text { content under study }\end{array}$ & $\begin{array}{l}\text { Whiteboard, PC, } \\
\text { projector, videos, } \\
\text { multimedia, } \\
\text { PowerPoint, podcasts, } \\
\text { available mobile } \\
\text { technologies }\end{array}$ & $\begin{array}{l}\text { Presentation and delivery of } \\
\text { proposed solution for } \\
\text { problems in small groups. } \\
\text { Analysis and debate of the } \\
\text { different solution perspectives. }\end{array}$ \\
\hline $\begin{array}{l}\text { Practical class } \\
\text { (reflection) }\end{array}$ & $\begin{array}{l}\text { Blended (partly } \\
\text { face-to-face) }\end{array}$ & $\begin{array}{l}\text { Perceptions of the } \\
\text { process followed } \\
\text { through the PBL, } \\
\text { learning of content, } \\
\text { teamwork skills } \\
\text { developed }\end{array}$ & $\begin{array}{l}\text { Discussion forum, } \\
\text { Wiki, rubrics, course } \\
\text { platform }\end{array}$ & $\begin{array}{l}\text { Evaluation of the current state } \\
\text { of acquired knowledge, } \\
\text { strategies employed, } \\
\text { performance of team } \\
\text { members, analysis of new } \\
\text { problems which may arise. } \\
\text { Application of self-evaluation } \\
\text { and team-work rubrics. } \\
\text { Completion of the CAPABP } \\
\text { questionnaire }\end{array}$ \\
\hline
\end{tabular}

Table 1. Distribution of the consideration of learning content in each sub-theme according to the PBL model employed (Adapted from "Problem-Based Learning in Multimodal Learning Environments: Learners’ Technology Adoption Experiences (Ioannou et al., 2016)) 
Further, it can be seen that the use of educational technology (ET) for the improvement of PBL processes has gone hand in hand with the development of traditional proposals (Koschmann, Kelson, Feltovich \& Barrows, 1996; Hung, Jonassen \& Liu, 2008; Donelly, 2010). In engineering, technology has been incorporated in concert with the characteristics of each institution and its students, following proposals made by Koschmann and Stahl (1998). These authors suggest that problems be presented through scenarios, diagrams, dialogue, video, multimedia and other formats (Barret, 2005). Further, the process is developed through four fundamental stages: Recognition, research, report and reflection.

The model applied to the present research combines, at a theoretical level, two of the variants proposed by Savin-Baden (2014). The first, PBL for knowledge management, seeks to develop a student who is competent in the management and resolution of problems in real contexts. Aiming for students to be capable of interpreting and understanding the knowledge behind problems, in addition to its practical application. The second, PBL through activity, is employed in disciplines such as computing and engineering (Booth \& White, 2008). It is used to favour student participation in learning and commitment to teamwork. Next, model implementation was conducted in a similar way to the approach taken by Ioannou, Vasiliou and Zaphiris (2016) in multi-modal settings and followed the four stages proposed by Koschmann and Stahl (1998) (see Table 1).

\subsection{Perceptions and Influence of PBL within Students of Engineering in Computer Sciences}

Students' attitudes and perceptions towards their experiences of PBL reveal a common consensus. They are seen to favour the understanding of learning content and its application in practice. This is due to the way that PBL helps to develop professional skills, critical thinking and self-directed learning, with a consequent impact on the performance and academic success of students (Hande et al., 2015; Dagyar \& Demirel, 2015; Dalfaro et al., 2017; Fernández \& Duarte, 2013).

In this sense, experiences are found, such as those reported by De Camargo-Ribeiro (2008), which are oriented towards the analysis of PBL. Students perceive this to be an attractive and interesting way to construct their own knowledge and develop the skills of research, communication, teamwork, problem solving, analysis and information synthesis. Yadav et. al (2011) evaluated the learning perceptions and conceptual understanding regarding employment of a PBL and traditional methodology. These authors found that students receiving PBL perceived and demonstrated better preparation when applying content to problem-solving, whilst also being more capable of transferring this to new situations. In the same way, Jaeger and Adair (2014) analysed the perceptions of engineering students following the introduction of a PBL methodology based on individual situations, motivation and perceived ability for success. Results outlined the need for mediation of the process by a facilitator, students' individual and collective responsibility for tasks, and the positive influence of one's individual situation on project quality. Research conducted by McLoone et al. (2016) recorded and analysed student's attitudes towards the use of project-oriented PBL. In this case, students rated the methodology to be positive, motivating and an effective way of managing to learn content. These students also stated that the process had led to improvements in communication, developed teamwork skills and prepared them for later professional practice.

Further, it is also useful to highlight that various research studies have outlined benefits associated with teamwork within organisations and businesses (Torrelles, París, Sabrià \& Alsinet, 2015), suggesting that competencies associated with this aspect are amongst the most important and in-demand for employers (Barraycoa \& Lasaga, 2009). As stated by Torrelles (2011), it is the:

Set of knowledge, skills and attitudes that enables collaboration with other individuals in the performance of activities in order to reach common goals, exchanging information, distributing tasks, taking on responsibilities, resolving difficulties that arise and contributing to collective improvement and development (Torrelles, 2011: page. 209).

A number of studies have made it their aim to evaluate the performance level achieved by students with regards to their development of professional skills through active methodologies (De Miguel, 2006; Schmal, 2015). PBL has been one of the methods to demonstrate the best results in this sense. This is true 
in relation to examination of its effectiveness for developing teamwork skills, self-directed learning, spoken and written communication, leadership, and other aspects (Fernández \& Duarte, 2013; Robledo, Fidalgo, Arias \& Álvarez, 2015; Warnock \& Mohammadi-Aragh, 2015; Macho-Stadler \& Elejalde-García, 2013; McLoone et al., 2016).

Evaluation of teamwork skills in different academic disciplines has largely been conducted through rubrics or scoring guides (Badia \& Vila, 2013; París-Mañas, Mas-Torelló \& Torrelles-Nadal, 2016; Yarosh, Serbati \& Seery, 2017). In engineering, students' perceptions and attitudes regarding the development of this skill has generally been analysed via questionnaires (Robles-Obando, 2013; Evangelia, Lakiotaki \& Matsatsinis, 2014; Warnock \& Mohammadi-Aragh, 2015; Macho-Stadler \& Elejalde-García, 2013). In all cases, results demonstrate the effectiveness of PBL in this regard.

\section{Methodology}

This proposal is developed under the design-based research paradigm (Rinaudo \& Donolo, 2010; Kennedy-Clark, 2013). It responds to problems detected in educational practice in relation to engineering careers with traditional curricula. It starts from the lack of teaching-learning strategies and methods to enable the development of professional competencies. In an attempt to find a solution to this lacking, an active method was administered in order to meet formulated objectives.

The research design was descriptive and correlations. If took a mixed approach, sequentially integrating data produced by qualitative and quantitative instruments (Creswell, 2014). A quasi-experimental design was specified with development, pre- and post- intervention phases. Non-probabilistic convenience sampling was used. A study control group was recruited (CG) and administered a traditional methodology, whilst an experimental group (EG) received PBL methodology according to the stages defined in the design section (see Figure 1). At the end of the intervention, data associated with academic performance in both groups was examined in order to compare the achievements derived. In the EG, measurements were taken, prior to and following intervention, of perceptions regarding the teamwork engaged in and attitudes towards the use of PBL in the Discrete Mathematics 2 (DM2) course.

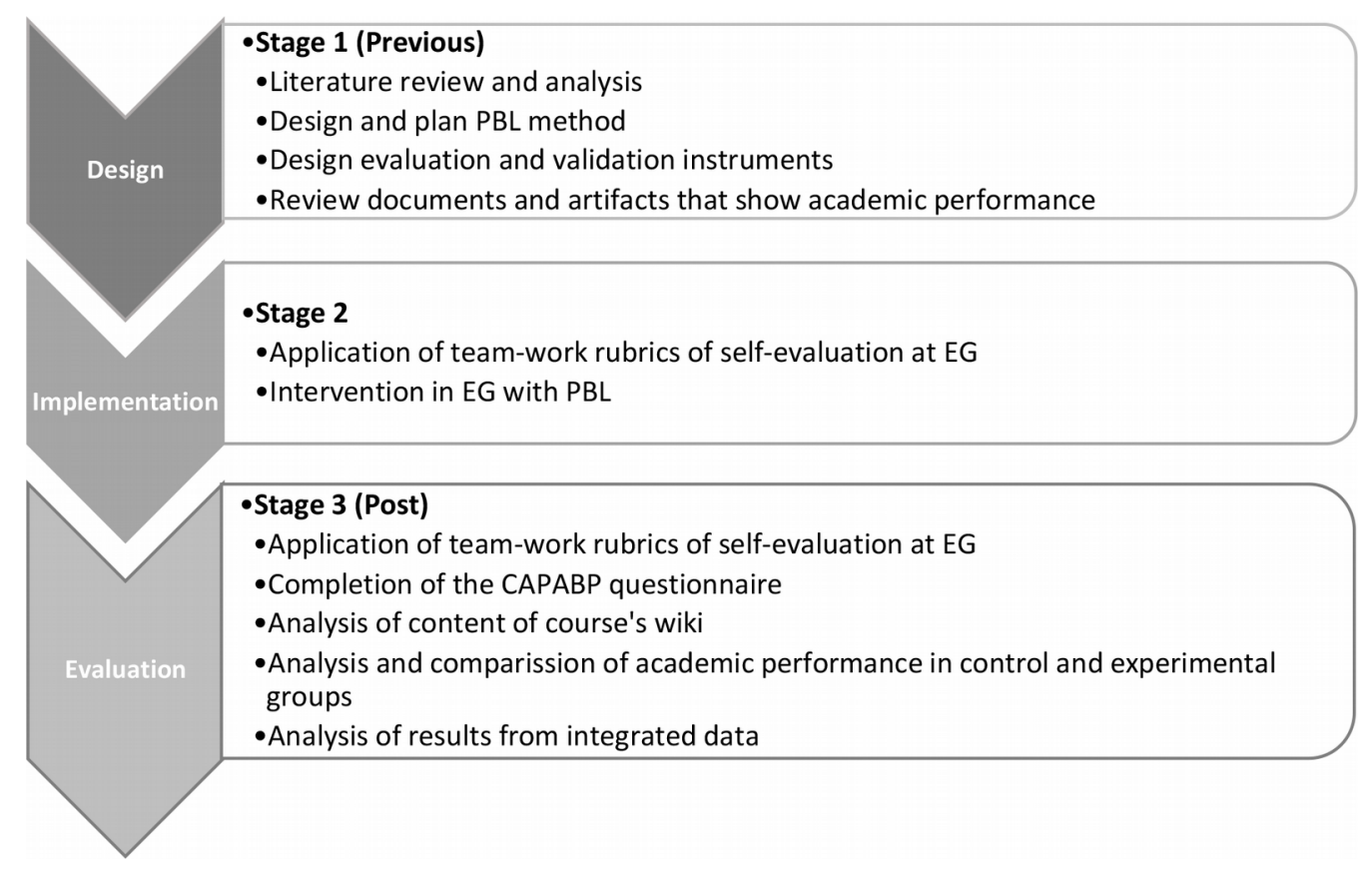

Figure 1. Research design stages 


\subsection{Study Participants}

The research was conducted within the Engineering and Computer Sciences degree course. All processes were conducted during the second semester of the 2017-2018 academic course. Sample characteristics are presented in Table 2.

Relative to males, a lower proportion of females enrol on degree courses in STEAM subjects (Hirshfield \& Koretsky, 2018). This aspect is evidenced by the population distribution of the present sample.

\begin{tabular}{|c|c|c|c|}
\hline \multicolumn{2}{|c|}{ Variable } & CG & EG \\
\hline \multicolumn{2}{|c|}{ Year of study } & $1^{\text {st }}$ & $1^{\text {st }}$ \\
\hline \multicolumn{2}{|c|}{ Age range } & $18-21$ & $18-21$ \\
\hline \multirow{2}{*}{ Sex } & Female & $13 / 32.5 \%$ & $15 / 38.5 \%$ \\
\hline & Male & $27 / 67.5 \%$ & $24 / 61.5 \%$ \\
\hline \multicolumn{2}{|c|}{ N. total $=79$} & $\mathrm{~N}=40$ & $\mathrm{~N}=39$ \\
\hline \multicolumn{4}{|c|}{$N$ - number of elements } \\
\hline
\end{tabular}

Table 2. Distribution and characteristics of the present student sample

\subsection{Instruments}

Academic performance was analysed using Official Records of Evaluation and Control (Registros Oficiales de Evaluación y Control, ROEC) for the degree course for both the EG and CG. Post-intervention, the same objective test was carried out in both groups which evaluated content referring to problem solving in Graph Theory. Figure 2, showed in the following sub-section, presents an example of the type of question asked to evaluate, at an application level, the objective related to the subject under study. This test is targeted towards the evaluation system of the discipline and is established in the analytical program of the degree course. This program is reviewed and updated each semester, and is published on the university's support platform for students.

The analysis is similar for all students. This grants it objectivity and responds to the use of the tool for determining final exam scores. In this way, a comparison could be made between the acquisition of learning content related to the topic being studied, between the EG who followed PBL methodology and the CG who worked with a traditional methodology.

The median test was employed to examine whether study groups were comparable and to compare the average scores of both groups following intervention. This non-parametric technique is adjusted to the sample size and to the type of data used in the study.

A questionnaire was also used as another instrument. This was administered to evaluate the attitudes and perceptions of students towards PBL (Cuestionario sobre las Actitudes y Percepciones del estudiantado sobre el Aprendiraje Basado en Problemas, CAPABP) (Hande et al., 2015) and was translated into Spanish. This instrument comprises a total of 15 items, distributed according to three domains: Knowledge acquisition, generic skills and attitudes towards PBL. In order to determine construct validity, factor analysis was performed using the maximum likelihood methods of extraction with orthogonal varimax rotation. A value of .735 was obtained for the Kaiser-Meyer-Olkin measure of sampling adequacy and a significance value of .000 for the Bartlett sphericity test. These outcomes permitted us to proceed with further analysis. Further, all variables exhibited commonality values higher than .600 . These results confirm the three considered domains, explaining $80.861 \%$ of total variance and largely conforming to the initial internal questionnaire structure $\left(\chi^{2}=88.007\right.$, with a significance value of .000$)$. Instrument reliability was evaluated by calculating Cronbach alpha values, achieving the values presented in Table 3 ( $\mathrm{p} \leq .05$, with $95 \%$ confidence levels also shown). 


\begin{tabular}{|l|r|r|r|r|}
\hline \multicolumn{1}{|c|}{ Domain } & No. items. & \multicolumn{1}{c|}{ alfa } & M & \multicolumn{1}{c|}{ SD } \\
\hline Content & 8 & .805 & 4.3750 & .28092 \\
\hline Competencies & 5 & .800 & 4.2205 & .59435 \\
\hline Attitudes & 3 & .708 & 4.2821 & .55429 \\
\hline General & $15^{*}$ & .909 & & \\
\hline
\end{tabular}

* Item 12 appears in two domains.

Table 3. Overall reliability analysis and stratified according to domain of CAPABP $(N=39)$

Perceptions of teamwork prior to and following intervention was measured using a teamwork self-report rubric (Yarosh et al., 2017). This differentiated three performance levels for each of the six established indicators.

For qualitative analysis of students' perceptions in relation to PBL methodology and work conducted using this method, individually developed Wikis were enabled. Emerging perceptions were analysed through content analysis with the software AQUAD 6. In accordance with the type of research, the frequency of code appearances was counted and frequency percentages were analysed. 12 recording units were coded: Oral and written communication, teamwork, acquisition of learning content, collaboration and information exchange, team dynamics, practical application of content, problem solving, skills, self-learning, applied technologies, problem-based learning and conflict resolution.

In order to facilitate the process of data collection and analysis, the courses learning management system (LMS) was used as an adjunct to the administration of questionnaires, rubrics and Wiki reflections. Quantitative data were analysed through the software SPSS v.22.

\subsection{Procedure for the Implementation of PBL}

PBL was applied during the second semester of the first year of study on the topic of Graph Theory, belonging to the subject of Discrete Mathematics 2. Graph Theory is based on discrete and applied mathematics, and is born out of concepts that come from diverse knowledge areas such as algebra, arithmetic, probabilities and topology, and combined areas (Diestel, 2005). It was conceived in 1736 when Euler (1736) published the article "Solutio problematis ad geometriam situs pertinentes". This was directly linked to topology and is considered to be the first theoretical output of the theory. Its theoretical basis was developed, historically, from contributions made by researchers such as Kirchhoff, Guthrie, Cayley, König, Dijkstra and Kuratowski, amongst others. This has directly influenced computer sciences, computing and telecommunication due to the viability that is offers for processes optimization, routing, flowcharts, search algorithms and network analysis (Rosen, 2012). In this way, the study of graphs has become a standard topic in subjects within this branch of study, particularly within the content of subjects from the discipline of Artificial Intelligence (AI). It is integrated into the Engineering in Computer Sciences curriculum as a section of content which corresponds to the Discrete Mathematics 2 module. This forms part of the computational intelligence discipline which includes discrete and applied mathematics and AI.

In the study plan, this topic is made up of two sub-themes: Notions about graphs, and special routing and planarity. The time distribution attributed to study this topic, in both the control and experimental group, can be seen in table 4 . Each activity comprises a total of two hours of classes.

\begin{tabular}{|c|c|c|c|c|c|c|c|c|c|c|}
\hline \multirow[b]{2}{*}{ EG } & \multicolumn{4}{|c|}{ Subtheme 1} & \multicolumn{4}{|c|}{ Subtheme 2} & & \\
\hline & $\begin{array}{c}\mathrm{L} \\
\mathrm{Rec}\end{array}$ & $\begin{array}{l}\text { PC } \\
\text { Res }\end{array}$ & $\begin{array}{l}\text { PC } \\
\text { Rep }\end{array}$ & $\begin{array}{l}\text { PC } \\
\text { Ref }\end{array}$ & $\begin{array}{c}\mathrm{L} \\
\mathrm{Rec}\end{array}$ & $\begin{array}{r}\text { PC } \\
\text { Res }\end{array}$ & $\begin{array}{l}\text { PC } \\
\text { Rep }\end{array}$ & $\begin{array}{l}\text { PC } \\
\text { Ref }\end{array}$ & Workshop & \multirow[t]{2}{*}{ Objective test } \\
\hline CG & $\mathrm{L}$ & PC & $\mathrm{PC}$ & PC & $\mathrm{L}$ & PC & PC & PC & Seminar & \\
\hline
\end{tabular}

L: Lecture, PC: Practical class, Rec: Recognition, Ref: Reflection, Rep: Report, Res: Research.

Table 4. Time distribution of the intervention in the experimental (EG) and control group (CG). 


\subsubsection{PBL Design for the Experimental Group}

When designing the PBL delivered to the EG, a number of guidelines established in the consulted literature were considered. This approach is based on the idea that knowledge construction is carried out in a flexible way, through the collaborative working of students when faced with real-world problems and contexts, in this way strengthening meaningful learning development. In this sense, it is assumed that the nucleus of learning activities lies within the problem itself and that the process is not linear. Further, problem generation should not be a simple task, ensuring its relevance, appropriate complexity and appropriateness to real contexts.

PBL was developed according to the four stages of the model proposed by Koschmann and Stahl (1998) and re-asserted by Ioannou et al. (2016): Recognition, research, report and reflection. Executed actions are presented under the first subtheme in Table 1. Analogously, the sequence used when considering the second subtheme was similar, with the exception of the introductory lecture given at the beginning which did not have to be repeated again later. In summary, the following actions were developed in each stage:

1. Recognition: Students developed the general problem analysis and acknowledged learning problems through the lesson imparted and educational resources provided by the tutor. An example of the type of problems to be resolved in PBL can be seen in figure 2.

2. Research: In relation to this theme. Self-directed and collaborative study was conducted of the learning content required to respond to identified learning problems.

3. Report: Here, teams met to apply the information obtained from problem solving. Groups developed and presented potential solutions to problems, analysing and debating the different perspectives relating to the possible solution.

4. Reflection: Here, the state of acquired knowledge, strategies employed, performance of team members and analysis of new problems which could arise were evaluated. Finally, students completed administered rubrics and questionnaires.

Given that it was the first time that a properly structured teamwork dynamic was applied and that this took place with a group of first-year students, support materials were distributed to ensure the appropriate working of teams. The former positively impacted upon team performance and work with the educational resources available on the course platform for learning self-management.

When distributing teams, individual student characteristics were considered, mainly academic performance in the subject up until the point of intervention. Imbalance relating to the learning level of members was avoided. Teams integrated between 3 and 5 students and counted on their lecturer who acted as a facilitator (Prince \& Felder, 2006).

The scant or non-existent experience of students in the design and production of educational resources, required consultation materials to be available which served as a guide when elaborating scripts. Classrooms and laboratories were made available for group work sessions. Laboratories were conceived as a viable alternative given certain access difficulties, as it could not be guaranteed that all students had electronic devices with the necessary capabilities for ubiquitous access to information, the internet and resources. To this effect, instructions given around the presentation of deliverable artefacts as evidence of learning were made in consideration of available technology within the reach of those involved. 


\section{Telephony network}

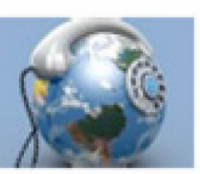

The telephone network installed at the Introductory Faculty of Computer Sciences has a number of devices arranged as shown in the figure. From a series of breakdowns caused by Hurricane Mitchel, a technician from the Cuban Telecommunications Company S.A (ETECSA, acronym in Spanish) receives the mission to repair it, having to verify all network points to check the connections.

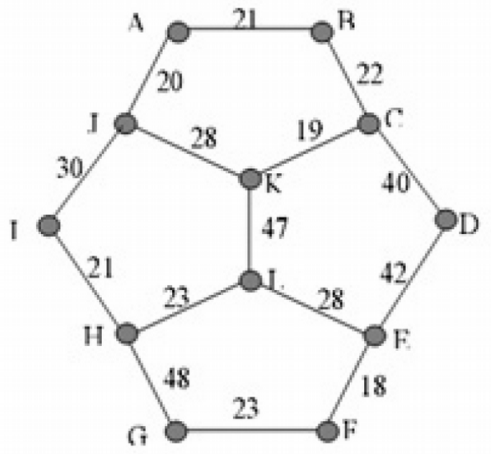

a) a) Will it be able to emit a signal from a connection point that goes through all the rest without repeating any and receiving the same one in return? If the answer is negative, propose a model for the network adding the minimum number of possible connections.

b) Using the original network model, the technician decides to review all sections of the network to detect possible failure. Can you do it without going through the same stretch twice?

c) It has also been decided to renew all the nodes of the network, but due to connection problems, two directly connected nodes cannot be made of the same material. How many different materials are needed to manufacture the nodes?

d) Will there be a couple of nodes that, if out of service, prevent the connection between the remaining nodes?

Figure 2. Problem (learning situation) designed for the PBL in the EG

\subsubsection{Methodology Used in the Control Group}

The traditional methodology applied within the CG was based on the delivery of theoretical lectures, one for each aforementioned topic, respectively. Six practical classes (PC) were run. Classes were evenly distributed and integrated a seminar presentation which closed the subject course. In relation to the lectures $(\mathrm{L})$, presentational methods were favoured in which the lecturer discussed the learning content that would, in later practical activities, lead to skill development. PC were developed based on initial lecturer orientation of exercises and problems at the beginning of each session, students then working individually to find solutions and, finally, spending time to review the responses given on the whiteboard. Evaluation of whether learning objectives were met was performed by the lecturer. This was conducted using a work checklist, shared with students on the whiteboard or in notebooks, and through systematic written or oral evaluation results.

\section{Results}

Results of the present research are presented with respect to the three proposed objectives.

Firstly, for the analysis of academic performance a test of homogeneity was applied in order to determine whether study groups were comparable. The result revealed that significant differences did not exist following application of the median test, verifying that the analysis was viable according to a $95 \%$ confidence level (theoretical $\chi^{2}=3.841$; empirical $\chi^{2}>2.930$ ). Considered hypotheses were $\mathrm{H}_{1}$ : Statistically significant differences exist between the EG and the CG; and the null hypothesis, $\mathrm{H}_{0}$ : Statistically significant differences do not exist between the EG and CG. The combined median of all elements was $M d n=3$, and it was later verified that the treatment given to the EG through PBL affects student's academic performance $\left(95 \%\right.$ confidence level; $\mathrm{df}=1$; theoretical $\chi^{2}=3.841$; empirical 
$\chi^{2}<4.250$ ). Table 4 presents the statistical comparison between the EG and CG following administration of the intervention.

\begin{tabular}{|c|r|r|r|r|r|}
\cline { 2 - 6 } \multicolumn{1}{c|}{} & \multicolumn{1}{c|}{ N } & \multicolumn{2}{c|}{ M } & \multicolumn{1}{c|}{ SD } & \multicolumn{1}{c|}{$\mathbf{s}^{\mathbf{2}}$} \\
\cline { 2 - 7 } \multicolumn{1}{c|}{} & Statistic & Statistic & Standard error & \multicolumn{1}{c|}{ Statistic } & \multicolumn{1}{c|}{ Statistic } \\
\hline CG & 40 & 3 & 0.16013 & 1.01274 & 1.026 \\
\hline EG & 39 & 3.4615 & 0.16773 & 1.04746 & 1.097 \\
\hline valid N (listwise) & \multicolumn{5}{|c}{39} \\
\hline
\end{tabular}

Table 4. Post-test descriptive statistics

Scores achieved in the objective tests performed following intervention was measured in both groups using a quantitative scale which ranged from $2-5$ points, with 2 representing the lowest score (fail). The percentage of those who passed, taken as an indicator of academic performance, was $60 \%$ and $79.49 \%$ in the CG and EG, respectively. This evidences a significant difference between both groups. It was highlighted that the number of students to achieve maximum scores in the EG was double that seen in the CG. This result may be partly attributed to the extent of meaningfulness achieved through PBL when faced with practical real-world problems. In this respect, comments left by students in the course Wiki included "...we are better prepared because we are faced with problems of daily life" (X). In another sense, this difference could also be attributed to an increase in problem solving skills, with this objective being evaluated in the objective tests pertaining to the subject program. In this respect, some students stated "the PBL learning methodology is really good because it helps us to understand the way in which to resolve problems, it gives us skills to know how to tackle the difficulties that could be presented to us in the course of problem solving" (C). Further, it is reasonable to acknowledge that the number of students who failed the course in the CG was also double that of the EG. This is due to the fact that problem solving skills are some of the most complex to acquire in this subject. In this sense, the traditional methodology followed in the CG does not favour the development of skills to resolve problems, whilst this occurs natural in the EG due to PBL (see Figure 3).

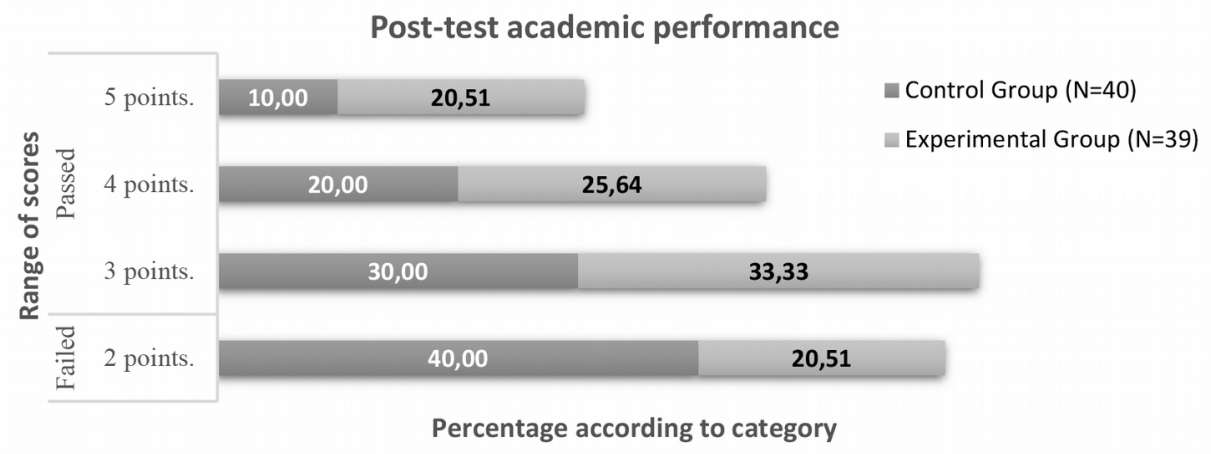

Figure 3. Post-test results of the objective tests applied in DM2

Secondly, following examination of students' attitudes and perceptions regarding the experience of PBL delivery, outcomes from the CAPABP questionnaire were considered. Response rate was $100 \%$, with a total of 39 questionnaires being completed in relation to the EG. There were no missing values. Table 5 shows the mean and standard deviation of questionnaire items, dividing according to domains:

Generally speaking, evaluated items received a satisfactory evaluation. The value of 4 (agree) was established as the median, with the mean being higher than this in all cases. Standard deviation values were between zero and one. This outcome suggests that student's experiences of PBL were well perceived, with highly positive evaluations being given to the surveyed domains. 


\begin{tabular}{|c|c|c|c|}
\hline \multicolumn{2}{|r|}{ Questionnaire items } & M (1-5) & SD \\
\hline \multicolumn{4}{|c|}{ Content } \\
\hline 1 & PBL helps you to better understand the topic being examined. & 4.36 & .668 \\
\hline 2 & PBL facilitates self-directed learning of students. & 4.31 & .655 \\
\hline 3 & Various hypotheses can be developed through PBL for a given problem. & 4.46 & .555 \\
\hline 4 & $\begin{array}{l}\text { In PBL it is possible to integrate prior knowledge into the context of the current } \\
\text { problem. }\end{array}$ & 4.36 & .628 \\
\hline 5 & In PBL it is possible to evaluate information collected in relation to a problem. & 4.36 & .668 \\
\hline 6 & This form of learning promotes the development of decision-making skills. & 4.33 & .737 \\
\hline 9 & PBL improves information processing skills & 4.41 & .637 \\
\hline 15 & $\begin{array}{l}\text { You learn to critically analyse the information presented by other group members } \\
\text { for discussion. }\end{array}$ & 4.41 & .595 \\
\hline \multicolumn{4}{|c|}{ Competencies } \\
\hline 7 & PBL teaches you to express ideas to the group in an effective way. & 4.36 & .743 \\
\hline 8 & PBL provides opportunities for improving leadership skills. & 4.03 & .932 \\
\hline 10 & It allows you to communicate effectively to the group. & 4.31 & .800 \\
\hline 11 & PBL helps students to participate without having to always give direction. & 4.18 & .823 \\
\hline 12 & In PBL you learn to respect the opinions of others within the group. & 4.23 & .667 \\
\hline \multicolumn{4}{|c|}{ Attitudes } \\
\hline 12 & In PBL you learn to respect the opinions of others within the group. & 4.23 & .667 \\
\hline 13 & $\begin{array}{l}\text { Students are able to identify their ethical and moral obligations with other group } \\
\text { members. }\end{array}$ & 4.28 & .793 \\
\hline 14 & You become aware of personal limitations while operating in an PBL group. & 4.33 & .621 \\
\hline
\end{tabular}

Table 5. CAPABP results (39 valid responses from the EG)

Item 3 is rated between 4 (agree) and 5 (strongly agree) by $97.4 \%$ of students. This could be due to the high feasibility of carrying out the analysis process from different perspectives, counting on diverse sources of information and educational resources made available by the tutor/lecturer. Further, the process is characterised by sharing spaces, the exchange of ideas and information, and making these ideas common knowledge amongst group members. This contrasts with the traditional methodology currently followed in this subject. In this case, work is not considered in the same collaborative way. This leads to the proliferation of one-dimensional thinking in students, with a limited view of problem-solving alternatives. In this domain, the least highly rated item was item 2 ( $94.9 \%$ of students reported scores of 4 or 5), although values were still high and were greater than the mean. Nonetheless, this result denotes that some students, despite positively rating the analysis and information processing in PBL, do not demonstrate cognitive Independence and, as a consequence, do not consider themselves competent to manage their own learning content.

In the second domain, evaluations of PBL are outlined as an alternative for favouring development of communication skills (items 7 and 10), with $89.7 \%$ and $84.6 \%$ of students, respectively, reporting scores of 4 and 5. Collaboration and information exchange with the tutor, team members and other classmates via the various established channels, enables development of fluid communication processes which use a number of the senses. The social presence of the tutor is essential for removing the barriers established for various reasons. In this respect, students indicate "...it helps us to a great extent to strengthen oral and written expression as during development of the issue at hand we are obliged to investigate different types of places, with different 
resources, with the aim of ensuring that work, objectives are reached" (S). Determined activities exist through which development of this competence is favoured. Such activities include the elaboration of artefacts as learning evidence for the evaluation of suggested solutions for problems, proposed interview script guides and the design of educational resources in the established way. The lowest score achieved was for the item associated with leadership (item 8). This could be linked to the fact that some students still stick to the false belief that the leader is the person who takes on most of the responsibility for tasks because they are more prepared, responsible and committed to their personal results. As a result, they show themselves to be resistant to taking on the role of leader, pointing to their own supposed inability and preparation. Subsequently, they limit their engagement to presenting the results found by the leader and fail to find a route within the chosen method to overcome their limitations. In the final domain, item 14 stands out ( $92.3 \%$ of students reported scores of 4 or 5 ). The team dynamic followed and the assumption of diverse roles permit students to self-evaluate their capacity for the performance of various tasks. This enables them to recognise their personal challenges and draw up a plan to address them, with this being done in function of the achievement of both individual and common team goals. On the other hand, the lowest score, whilst also being higher than the mean, was obtained for item 12 . This could be associated to the fact that some students consider that their opinions are not respected nor considered during the process of solving problems, thus, they appear to be considered irrelevant in analysis or lacking in depth and rigour.

In a general way, the domains of content and competencies are highly positively correlated $(\varrho=.816)$. Nonetheless, the most positive scores are found for the former, whilst the lowest score (although also highly positive) is given for the second domain. This situation could be due to the fact that problem solving is a transversal skill developed from primary education using traditional methodologies. The novelty of teamwork via PBL, following a correctly structured dynamic, favourably impacts upon content acquisition. This makes qualitative changes in the observed indicators perceptible. However, it is difficult to administer this given that the development of competencies in previous teachings has never previously been the object of analysis and it does not have a clear and specific system of performance indicators, nor does it count on the pathways or strategies to evaluate them. Administration is even more challenging when the teaching process is centred on the student and formative evaluations are performed which demand individual and group self-evaluations, processes with which students are not familiar with.

Given the size of the EG $(\mathrm{N}=39)$, the Shapiro-Wilk normality test was applied. This indicated that data did not follow assumptions of normality (statistics between .700 and $.800, d r=39$ and $p<0.05$ ). Following this, the non-parametric Spearman Rho test was applied to analyse correlations between grouped questionnaire domains. This obtained values $0.7<(\varrho<0.89)$ in all cases, denoting high positive associations.

Bivariate correlations (see Table 6) underline the values achieved between items 7 and 8 which are associated with communication $(\varrho=.715)$. A highly positive correlation between both items is evidenced. This may be attributed to the importance of the communication and expression of ideas throughout the entire process. This is crucial for collaboration, debate and information exchange regarding the research findings uncovered from self-directed learning and, finally, for the presentation of proposed solutions to learning situations for measuring available technologies.

As another aspect, the existing relationship between items 14 and $15(\varrho=.705)$ stands out, being equally highly positive as the aforementioned correlation. From this is can be understood that students become aware and acquire skills to make evaluative judgements about their actions and those of their course mates. This is facilitated by the prior establishment of specific performance indicators for each activity. In a similar way, a moderately positive correlation was found between the items of 5 and 7 ( $\varrho=.686$ ). This may be largely attributed to the search for, analysis and discussion of research findings, fit of solutions to problems, and the debate developed between the students and the rest of their work team. The plenary session for presenting results will also play a role in establishing this association. 


\begin{tabular}{|c|c|c|c|c|c|c|c|c|c|c|c|c|c|c|}
\hline \multirow{2}{*}{ C02 } & $.013 *$ & & & & & & & & & & & & & \\
\hline & $.936 * *$ & & & & & & & & & & & & & \\
\hline \multirow{2}{*}{ C03 } & .265 & .449 & & & & & & & & & & & & \\
\hline & .103 & .004 & & & & & & & & & & & & \\
\hline \multirow{2}{*}{ C04 } & .089 & .402 & .541 & & & & & & & & & & & \\
\hline & .588 & .011 & .000 & & & & & & & & & & & \\
\hline \multirow{2}{*}{ C05 } & .575 & .408 & .588 & .556 & & & & & & & & & & \\
\hline & .000 & .010 & .000 & .000 & & & & & & & & & & \\
\hline \multirow{2}{*}{ C06 } & .276 & .395 & .200 & .419 & .391 & & & & & & & & & \\
\hline & .089 & .013 & .223 & .008 & .014 & & & & & & & & & \\
\hline \multirow{2}{*}{ СР07 } & .573 & .245 & .255 & .296 & .686 & .531 & & & & & & & & \\
\hline & .000 & .133 & .118 & .068 & .000 & .001 & & & & & & & & \\
\hline \multirow{2}{*}{ СР08 } & .387 & .376 & .365 & .515 & .519 & .628 & .445 & & & & & & & \\
\hline & .015 & .018 & .022 & .001 & .001 & .000 & .005 & & & & & & & \\
\hline \multirow{2}{*}{ C09 } & .376 & .407 & .324 & .171 & .544 & .330 & .605 & .441 & & & & & & \\
\hline & .018 & .010 & .044 & .297 & .000 & .040 & .000 & .005 & & & & & & \\
\hline \multirow{2}{*}{ CP10 } & .495 & .270 & .318 & .480 & .653 & .545 & .715 & .538 & .411 & & & & & \\
\hline & .001 & .096 & .048 & .002 & .000 & .000 & .000 & .000 & .009 & & & & & \\
\hline \multirow{2}{*}{ CP11 } & .437 & .211 & .378 & .264 & .554 & .127 & .452 & .464 & .678 & .386 & & & & \\
\hline & .005 & .196 & .018 & .105 & .000 & .440 & .004 & .003 & .000 & .015 & & & & \\
\hline \multirow{2}{*}{ CPA12 } & .201 & .089 & .384 & .558 & .331 & .221 & .253 & .478 & .221 & .530 & .394 & & & \\
\hline & .221 & .591 & .016 & .000 & .040 & .176 & .120 & .002 & .176 & .001 & .013 & & & \\
\hline \multirow{2}{*}{ A13 } & .429 & .300 & .394 & .365 & .412 & .324 & .435 & .614 & .543 & .363 & .618 & .264 & & \\
\hline & .006 & .063 & .013 & .022 & .009 & .045 & .006 & .000 & .000 & .023 & .000 & .104 & & \\
\hline \multirow{2}{*}{ A14 } & .399 & .502 & .413 & .485 & .643 & .402 & .472 & .496 & .426 & .565 & .225 & .340 & .405 & \\
\hline & .012 & .001 & .009 & .002 & .000 & .011 & .002 & .001 & .007 & .000 & .168 & .034 & .010 & \\
\hline \multirow{2}{*}{ C15 } & .351 & .364 & .394 & .436 & .620 & .254 & .300 & .541 & .420 & .466 & .512 & .358 & .527 & .705 \\
\hline & .029 & .023 & .013 & .006 & .000 & .118 & .064 & .000 & .008 & .003 & .001 & .025 & .001 & .000 \\
\hline Spr* & \multirow{2}{*}{ C01 } & \multirow{2}{*}{ C02 } & \multirow{2}{*}{$\mathrm{C} 03$} & \multirow{2}{*}{ C04 } & \multirow{2}{*}{ C05 } & \multirow{2}{*}{ C06 } & $\mathrm{CP}$ & $\mathrm{CP}$ & \multirow{2}{*}{ C09 } & $\mathrm{CP}$ & $\mathrm{CP}$ & CPA & \multirow{2}{*}{ A13 } & \multirow{2}{*}{ A14 } \\
\hline Sig. (two-tailed)** & & & & & & & 7 & 8 & & 10 & 11 & 12 & & \\
\hline
\end{tabular}

Table 6. Bivariate correlations between the items of the CAPABP questionnaire applied post-intervention in the EG $(\mathrm{N}=39)$

Finally, a moderately positive correlation is distinguished between items 9 and 11 ( $\varrho=.678$ ). In this sense, the team dynamic established and the tasks relating to each role determine the active participation of all team members as a function of proposed objectives. Nonetheless, students who do not occupy leadership roles are generally more involved in the search, analysis and processing of information.

In keeping with the third objective, student's perceptions regarding the influence of PBL on teamwork skills was examined through the rubric used throughout the study. Results are observed in Table 7.

\begin{tabular}{|c|r|r|r|r|r|r|}
\cline { 2 - 7 } \multicolumn{1}{c|}{} & \multicolumn{2}{c|}{ Level 1 } & \multicolumn{2}{c|}{ Level 2 } & \multicolumn{2}{c|}{ Level 3 } \\
\cline { 2 - 7 } \multicolumn{1}{c|}{} & Pre & \multicolumn{1}{c|}{ Post } & \multicolumn{1}{c|}{ Pre } & \multicolumn{1}{c|}{ Post } & \multicolumn{1}{c|}{ Pre } & \multicolumn{1}{c|}{ Post } \\
\hline IND1 & 7.7 & 0.0 & 23.1 & 35.9 & 69.2 & 64.1 \\
\hline IND2 & 7.7 & 0.0 & 23.1 & 41.0 & 69.2 & 59.0 \\
\hline IND3 & 2.6 & 23.1 & 43.6 & 30.8 & 53.8 & 46.2 \\
\hline IND4 & 0.0 & 0.0 & 43.6 & 64.1 & 56.4 & 35.9 \\
\hline IND5 & 15.4 & 23.1 & 41.0 & 56.4 & 43.6 & 20.5 \\
\hline IND6 & 12.8 & 0.0 & 25.6 & 35.9 & 61.5 & 64.1 \\
\hline
\end{tabular}

Table 7. Comparison of teamwork perceptions prior to and following intervention in the EG (values given as a percentage of the total, $\mathrm{N}=39$ ) 
Prior to the intervention, the majority of students reported maximum self-evaluations scores (level 3) for each indicator. Indicators 1 and 2 are highlighted, "I actively participate and collaborate in team tasks" and "I promote trust and cordiality in group relations", respectively. Both received approximately $69 \%$ of the response total. Thus, these students considered themselves to be more capable of transmitting, debating and exchanging criteria and comments with the course mates in their group in relation to work. In this way, they maintain a climate of collaboration and support, promoting constructive dialogue. In the same way, indicator 6, "I coordinate the group, guaranteeing the achievement of results and positive performance" obtained around $62 \%$ of responses in Level 3. In this sense, a large number of respondents stated that they were capable of encouraging other team members to reach more difficult goals than those established.

Following the intervention, results varied significantly. All indicators in level 3 decreased, apart from the sixth indicator which showed a slight increase of approximately $2 \%$. Indicators 4 and 5 were most affected, "I act in a constructive way in order to resolve conflicts within the team" and "I coordinate the group, ensuring the integration and empowerment of members", respectively. Each of these indicators showed a decrease of close to $20 \%$ of students reporting the maximum level. In the case of the former indicator, most of these cases passed to level 2, whereas for the latter indicator, cases were distributed between levels 1 and 2. Nevertheless, it is possible to argue that the decline in positive evaluations following intervention does not necessarily imply a reduction in the initially reported level for teamwork skills. Instead, this could represent greater accuracy and self-evaluation due to greater knowledge of the previously established performance indicators. A similar effect could result from greater knowledge of the work dynamics displayed in the team and personal commitment to the application of a formative evaluation process, aspects that are characteristic of PBL. To this effect, one student indicated that "When working in a team it should not always be the leader who does everything, when we talk about teamwork we address this, a team in which each and every one of the "team" members should participate. Before, we did not know what is was to work. in a team, now we do. Whenever it functions in this way, the team will work well, where each of the members collaborates and gives their own opinion...” (D).

In the absence of prior experience with regards to the training and development of the aforementioned skill, over-evaluation of individual skills represents a tangible threat. This risk increases when individuals attempt to respond in the way in which they consider to be desired or considered correct by others. Further, through PBL, students become aware of the actual skills developed, with this influencing the final self-evaluation given.

Content analysis of the Wiki platform guided reflection on the development of competencies through PBL and perceptions relating to this. This was conducted by counting frequencies and percentages. Results are shown in Figure 4.

Results denote that students in the GE recognise the impact of PBL methodology on the development of skills in a general way and, particularly, in relation to teamwork, and oral and written communication. A total of 53 records are indicated in which participants observe standpoints such as "In my opinion I think that teamwork is very important given that through this we exchange knowledge about the topic we are developing, whilst it also allows you to educate yourself and incorporate and update our intellect, it helps to a great extent to strengthen oral and written expression as during the development of the problem at hand we are obliged to investigate in different types of places with the aim of guaranteeing good work".

In another sense, favourable criteria emerge in relation to the use of PBL methodology which are unprecedented in the Curriculum. The impact of these criteria can also be seen on the acquisition of learning content. Other opinions express that "PBL instils us with deeper knowledge at the time of studying given that in this way we are better prepared because we are faced with problems of everyday life" (X). This reveals student perceptions about the practical meaning of content. 


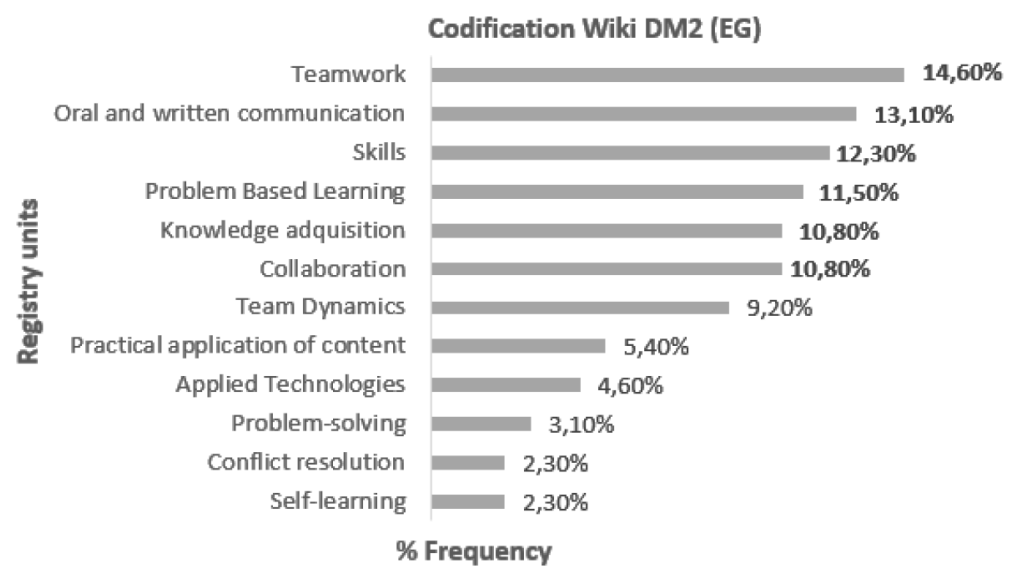

Figure 4. Main results of the frequency analysis of codes reported in the DM2 Wiki

\section{Discussion and Conclusions}

The present research was developed in an Engineering degree course with a traditional curriculum. It followed a mixed approach which integrated both qualitative and quantitative types of data. A quasi-experimental study was specified, comparing results obtained in a control group (CG) and an experimental group (EG). These groups represented a traditional methodology and PBL, respectively. Results of the present study corroborate findings reported in other empirical research studies which used a similar design and were conducted in engineering. These prior findings also supported the three objectives proposed in the present article and are discussed below.

With respect to the first objective, the results achieved indicate that academic performance in Discrete Mathematics is favoured when PBL is employed, in comparison with when a traditional methodology is used. An increase in the average score obtained in the CG was observed, following application of similar tests which measured learning content post-intervention. Present findings are in line with previously conducted research in which, in addition to better academic performance, students reported better performance when solving problems and applying content to practice (Polanco et al., 2004; Rodríguez \& Fernández-Batanero, 2016; Morss \& Billiar, 2016). In the same way, results agree with presented in a meta-analysis performed by Dağyar and Demirel (2015). This analysed 98 studies, of which 45 had been conducted within the higher education setting and employed similar designs to that utilised in the present research. This meta-analysis evidenced a large impact of PBL on academic success when compared with traditional teaching. However, this contrasts with findings reported by Dochy et al. (2003) which found evidence in 33 studies of a negative effect of PBL, relative to students taught in a conventional learning setting, on the knowledge base constructed. The difference between these two studies is presumably due to the accumulation of experiences following PBL application and the analysis of risks detected as threats in these research studies, aspects which were taken into consideration in later research.

With regards to the second objective, PBL was demonstrated to be greatly accepted by students. Students perceived meaningful gains in knowledge management and in the skills of teamwork and communication. All of these skills are highly rated by teachers and employers for the achievement of academic success and effective professional performance. The perceptions reflected in the applied instruments further highlight consensus in relation to the novelty of the methodology and its contribution towards the achievement of more solid learning, evaluations of the teaching process and involved individuals, and the application of learning content in real-world contexts. This is in line with findings reported by Mitchell, Canavan and Smith (2010) who found that students perceived PBL to be highly effective in promoting the development of transferrable skills, skills that are highly valued by employers. As has also been highlighted by these same authors, as process of adaptation to PBL is required. This is because the use of traditional methodologies, where poor practice and inappropriate group dynamics prevail, provoke distrust and uncertainty at the time of tackling group tasks. 
In the same way, this positively impacts upon the opportunities offered by PBL for approaching problem solving from different perspectives. This issue is conditioned by the availability of multiple educational resources for self-directed learning and the social presence of the tutor to provide the accompaniment and support pertinent to the process. This characteristic is unusual in traditional methodologies which conditions one-directional and convergent thinking, in which interaction between actors is reduced.

In accordance with other research studies, workload was observed to increase considerably with PBL for both teachers and students (Macho-Stadler \& Elejalde-García, 2013). Nonetheless, both of these expressed conformity with the process with regards to feeling motivated by the methodology and having addressed subject sub-themes with, at most, two learning situations. The former (feeling motivated), prevents symptoms of fatigue and tiredness from emerging, regardless of the extent of social presence and help shown by the tutor (Pyle \& Hung, 2019). It also demands the design and presentation of educational resources in diverse formats for each problem considered. In this sense, analysis of the impact of the workload imposed by PBL on academic performance in the other curricular subjects would be insightful. This could be examined in future research studies. It is understood that generalisation of PBL to other program topics will not guarantee satisfactory results if it only counts on the motivation of implicated staff. In this case, successful application to other ambits will depend on the various factors that are fundamentally associated with the curricular training model of the degree course and the objectives established, alongside their respective forms of evaluations. These aspects will have to be modified in order to focus on the outcomes of contemplating relevant processes.

Further, the communication and expression of ideas throughout the entire process was highly rated and considered essential for information exchange and the presentation of results. Nonetheless, the term collaboration was unknown in this context, despite recognising that PBL enables individuals to earn trust, leave shyness to one side and, in this way, be able to develop a fluid debate and assess the best potential solutions together. This drives the need to create spaces, prior to PBL intervention, to familiarise individuals with associated terms as indicated by Rodríguez \& Fernández-Batanero (2017).

In relation to the third objective, positive student perceptions were observed regarding the improvement of their teamwork skills following analysis of opinions expressed in relation to the communication spaces created to develop this competence. In this case, the relevant space pertained to the personal Wikis available in the course platform. Results point to full engagement with the teamwork conducted in PBL. An effective work dynamic was established, with roles and tasks being defined by each member. This is entirely unprecedented, being absent from earlier educational stages. Nonetheless, a degree of rejection still prevails for assuming leadership roles. This is due to poor practice in that the leaders tends to be associated as the person in charge of executing all tasks during problem solving. Typically, traditional methodologies do not encourage collaboration and information seeking equally between all team members. This leads to a lack of knowledge around the function associated with each role within a team and a lack of personal commitment to the execution of tasks. In making available different spaces and resources for collaboration and permitting further evaluation of both individual and group contributions to performing common tasks, favourable perceptions of the process emerged.

It is necessary to highlight that fluctuating self-perceptions of teamwork were reported by students following administration of the post-intervention rubric. In this sense, results recorded a decrease in scores due to the initial lack of knowledge about skill performance indicators, desired levels and forms of measurement. A consequence of this is that students may overrate their actual abilities. Following intervention, evaluations were more objective and accurate. As students were in their first academic year and so could not call on references with regards to working on this skill in previous learning experiences, their scarce or non-existent of an effective team dynamic negatively impacted upon outcomes.

The absence of actions oriented towards the training and development of skills at all levels of learning in the Cuban educational system, in addition to the use of active methodologies, proved to be a limitation of the present study as it sought to examine these approaches in this context. Lack of knowledge of the theoretical support associated with PBL, the teamwork dynamic, and roles and functions of implicated 
individuals, affects the execution of the process. This is because additional time is required for the training of teaching staff charged with exercising the role of facilitator, the explanation of concepts, PBL processes and evaluation approaches, and the design of educational resources to cover these topics.

In accordance with Robledo et al. (2015), we consider that PBL demands commitment from students and their engagement in the learning process. This requires students to put into action their higher order thinking skills. It also demands management of human resources, and methodological and technological resources, making implicated individuals aware of the greater practical application of this method and its link with future professional performance.

Despite the validity of the achieved results, questions remain regarding the factors that might have led to them given that an uncommon dynamic was introduced into the traditional curriculum. It is worthwhile to question to what extent the breakdown of problems into sub-problems and the availability of a greater number of educational resources on the virtual platform impacted results. These questions are in line with those posed in the study reported by Latasa et al. (2012), focusing towards cost-benefit analysis of PBL application within the traditional curricula of first-year students.

Finally, given the determining role and influence that learning technologies can exercise over the academic spoils of students, alongside the benefits reported in research studies when their incorporation is favoured (Ioannou et al., 2016; Okyere, Tawiah, Lamptey, Oduro \& Thompson, 2017; Nordin \& Subramaniam, 2013), we propose, as a future projection, that settings should improve their development of mediation methodologies such as PBL. This should take place through the gradual introduction of relevant technologies. In the present context, increasing costs of Internet access and the economic difficulties that students can face in obtaining any type of device or mobile technology are problematic as this represents the minimum requirement to support this learning process. Despite this, the creation of group conditions in teaching laboratories is viable, as is the delegation of sufficient time for completing tasks relating to the search and exchange of information, an aspect highly rated by students.

\section{Declaration of Interest}

The authors declare that no potential conflicts of interest exist with respect to the research, authorship and/or publication of this article.

\section{Funding}

The authors declare that they have not received any financial support for the research, authorship and/or publication of this article.

\section{References}

Allendoerfer, C., Bates, R., Karlin, J., Ulseth, R., \& Ewert, D. (2015). Leading large-scale change in an engineering program. Paper presented at the American Society of Engineering Education Annual Conference and Expo. Seattle, WA. https://doi.org/10.18260/p.24397

Alves, A., Sousa, R.M., Fernandes, S., Cardoso, E., Carvalho, M.A., Figueiredo, J. et al. (2016). Teacher's experiences in PBL: Implications for practice. European Journal of Engineering Education, 41(2), 123-141. https://doi.org/10.1080/03043797.2015.1023782

Arana-Arexolaleiba, N., \& Zubizarreta, M.I. (2015). The impact of PBL learning environment and supervision of engineering faculty of Mondragon University in the student learning approach. In E. de Graaff, A. Guerra, A. Kolmos, \& N. Arana-Arexolaleiba (Eds.), Global research community: Collaboration and developments, 2016/VII (479-491). Aalborg: Aalborg University Press.

Badia, M., \& Vila, B. (2013). Rúbricas para la evaluación de competencias. Trabajo en equipo. Cuadernos de Docencia Universitaria, 26. Octaedro. 
Barraycoa, J., \& Lasaga, O. (2009). Competencias e inserción laboral: un análisis de la empleabilidad en los recién licenciados en Ade y Economía. Madrid: CEU Ediciones.

Barrett, T. (2005). What is problem-based learning. In O’Neill, G., Moore, S., \& McMullin, B. (Eds.), Emerging issues in the practice of university learning and teaching (55-66). Dublin, Ireland: AISHE. Available at: http://www.aishe.org/readings/2005-1/

Barrows, H.S. (1986). A taxonomy of problem-based learning methods. Medical Education, 20(6), 481-486. https://doi.org/10.1111/j.1365-2923.1986.tb01386.x

Bates, R., \& Ulseth, R. (2013). Keynote: RosEvaluation conference 2013. Terre Haute, IN: Rose Hulman Institute of Technology.

Booth, G., \& White, P. (2008, July). Innovative curriculum development within the Motorsport B. Eng course at Coventry University. Proceedings of the Engineering Education 2008 International Conference on Innovation, Good Practice and Research in Engineering Education, Loughborough University, UK. Retrieved from: http://www.engsc.ac.uk/downloads/scholarart/ee2008/p032-booth.pdf

Creswell, J.W. (2014). Research Design: Qualitative, Quantitative, and Mixed Methods Approaches. SAGE Publications, Inc.

Dağyar, M., \& Demirel, M. (2015). Effects of Problem-Based Learning on Academic Achievement: A Meta-Analysis Study. Education and Science, 40(181), 139-174. https://doi.org/10.15390/EB.2015.4429

Dalfaro, N.A., Del Valle, C.G., \& Aguilar, N.F. (2017) La aplicación del Aprendizaje Basado en Problemas en carreras de Ingeniería. 1er. Congreso Latinoamericano de Ingeniería. Entre Ríos, Argentina, 13-15. https://doi.org/10.26507/rei.v13n25.859

De Camargo-Ribeiro, L.R. (2008). Electrical engineering students evaluate problem-based learning (PBL). International Journal of Electrical Engineering Education, 45(2), 152-161. https://doi.org/10.7227/IJEEE.45.2.7

De Miguel D.M. (Dir.) (2006). Metodologías de enseñanza y aprendizaje para el desarrollo de competencias. Orientaciones para el profesorado universitario ante el espacio europeo de educación superior. Alianza Editorial. Madrid.

Diestel, R. (2005). Graph Theory. New York: Springer-Verlag Heidelberg.

Dochy, F., Segers, M., Van den Bossche, P., \& Gijbels, D. (2003). Effects of problem-based learning: a meta-analysis. Learning and Instruction, 13(5), 533-568. https://doi.org/10.1016/S0959-4752(02)00025-7

Donnelly, R. (2010). Harmonizing technology with interaction in blended problem-based learning. Computers \& Education, 54(1), 350-359. https://doi.org/10.1016/j.compedu.2009.08.012

Evangelia, K., Lakiotaki, K., \& Matsatsinis, N.F. (2014). Adopting a strategy for enhancing generic skills in engineering education. Industry \& Higher Education, 28(3), 185-192. https://doi.org/10.5367/ihe.2014.0206

Euler, L (1736). Solutio Problematis ad geometriam situs pertinentis, Commentarii Academiae Scientiarum Imperialis Petropolitanae, 8, 128-140.

Fernández, F.H., \& Duarte, J.E. (2013). El aprendizaje basado en problemas como estrategia para el desarrollo de competencias específicas en estudiantes de ingeniería. Formación Universitaria, 6(5), 29-38. https://doi.org/10.4067/S0718-50062013000500005

Fernández-March, A. (2006) Metodologías activas para la formación de competencias. Educatio siglo XXI, 24, 35-56.

Gijbels, D., Dochy, F., Van den Bossche, P., \& Segers, M. (2005). Effects of problem-based learning: A meta-analysis from the angle of assessment. Review of Educational Research, 75(1), 27-61.

https://doi.org/10.3102/00346543075001027 
Graaff, E., \& Kolmos, A. (2007). History of problem-based and project-based learning. In Graaff, E.D., \& Kolmos, A. (Eds.), Management of Change: Implementation of Problem-Based and Project-Based Learning in Engineering (1, 221). Rotterdam, The Netherlands: Sense Publisher.

https://doi.org/10.1163/9789087900922_002

Guerra, A., Ulseth, R., \& Kolmos, A. (2017). PBL in Engineering Education. International Perspectives on Curriculum Change. Rotterdam, The Netherlands: Sense Publishers. https://doi.org/10.1007/978-94-6300905-8

Hande, S., Mohammed, C.A., \& Komattil, R. (2015). Acquisition of knowledge, generic skills and attitudes through problem-based learning: Student perspectives in a hybrid curriculum. Journal of Taibab University Medical Sciences, 10(1), 21-25. https://doi.org/10.1016/j.jtumed.2014.01.008

Hirshfield, L., \& Koretsky, M.D. (2018). Gender and Participation in an Engineering Problem-Based Learning Environment. Interdisciplinary Journal of Problem-Based Learning, 12(1).

https://doi.org/10.7771/1541-5015.1651

Hung, W. (2006). The 3C3R model: A conceptual framework for designing problems in PBL. Interdisciplinary Journal of Problem-based Learning, 1(1), 55-77. https://doi.org/10.7771/1541-5015.1006

Hung, W., Jonassen, D.H., \& Liu, R. (2008). Problem-based learning. In Spector, J.M., van Merrienboer, J.G., Merrill, M.D., \& Driscoll, M. (Eds.), Handbook of research on educational communications and technology (3rd ed., 485-506). Mahwah, NJ: Erlbaum.

Ioannou, A., Vasiliou, C., \& Zaphiris, P. (2016). Problem-Based Learning in Multimodal Learning Environments: Learners' Technology Adoption Experiences. Journal of Educational Computing Research. 54(7) 1022-1040. https://doi.org/10.1177/0735633116636755

Iron Range Resources (2010). Biennial report 2009-2010. Eveleth, MN: Iron Range Resources. Available at: http://mn.gov/irrrb/images/2009-2010/BiennialReport.pdf

Jaeger, M., \& Adair, D. (2014). The influence of students' interest, ability and personal situation on students' perception of a problem-based learning environment. European Journal of Engineering Education, 39(1), 84-96. https://doi.org /10.1080/03043797.2013.833172

Kaplan, F., \& Vinck, D. (2013). The practical confrontation of engineers with a new design endeavour. The case of the digital humanities. En Heywood, J. (Ed.), The Assessment of Learning in Engineering Education: Practice and Policy (265-266). The Institute of Electrical and Electronics Engineers, Inc., John Wiley \& Sons, Inc. https://doi.org/10.1201/b15792-4

Kennedy-Clark, S. (2013). Research by Design: Design-Based Research and the Higher Degree Research student. Journal of Learning Design, 6(2), 26. https://doi.org/10.5204/jld.v6i2.128

Kim, J.N., (2017). ProQuest, 10257538.

Kolmos, A, Fink F., \& Krogh L. (2004). The Aalborg PBL Model: progress, diversity and challenges. Aalborg: Aalborg University Press.

Koschmann, T., Kelson, A.C., Feltovich, P., \& Barrows, H.S. (1996). Computer-supported problem-based learning: A principled approach to the use of computers in collaborative learning. In Koschmann, T. (Ed.), CSCL: Theory and practice of an emerging paradigm (83-124). Mahwah, NJ: Lawrence Erlbaum Associates.

Koschmann, T., \& Stahl, G. (1998). Learning issues in problem-based learning: Situating collaborative information seeking. Panel at CSCW'98. Available at: http://gerrystahl.net/publications/conferences/1998/index.html

Kumar, D.D., \& Radcliffe, P. (2017). Problem Based Learning for Engineering. IEEE, 25-29.

https://doi.org/10.1109/EMBC.2017.8036754 
Lachiver, G., Dalle, D., Boutin, N., Clavet, A., \& Dirand, J.M. (2002). Competency and project-based programs in electrical \& computer engineering at the Universite de Sherbrooke. IEEE Canadian Review, 41, 21-24. Available at: http://bit.ly/2wzecoE

Latasa, I., Lozano, P., \& Ocerinjauregi, N. (2012). Aprendizaje Basado en Problemas en Currículos Tradicionales: Beneficios e Inconvenientes. Formación Universitaria, 5(5), 15-26. https://doi.org/10.4067/S0718-50062012000500003

Leary, H., Walker, A., Shelton, B.E., \& Fitt, M.H. (2013). Exploring the Relationships Between Tutor Background, Tutor Training, and Student Learning: A Problem-based Learning Meta-Analysis. Interdisciplinary Journal of Problem-Based Learning, 7(1). https://doi.org/10.7771/1541-5015.1331

Macho-Stadler, E., \& Elejalde-García, M.J. (2013) Case study of a problem-based learning course of physics in a telecommunications engineering degree. European Journal of Engineering Education, 38:4, 408-416. https:// doi.org/10.1080/03043797.2013.780012

McLoone, S.C., Lawlor, B.J., \& Meehan, A.R. (2016). The Implementation and Evaluation of a Project-Oriented Problem-Based Learning Module in a First Year Engineering Programme. Journal of Problem Based Learning in Higher Education, 4(1), 71-80. https://doi.org/10.5278/ojs.jpblhe.v0i0.1243

Ministry of Higher Education [MES] (2016). Documento base para el diseño de los Planes de Estudio "E". Available at: http://www.mes.cu

Mitchell, J.E., Canavan, B., \& Smith, J, (2010). Problem-Based Learning in Communication Systems: Student Perceptions and Achievement. IEEE Transactions On Education, 53(4), 587-594. https://doi.org/10.1109/TE.2009.2036158

Mohd-Yusof, K., Hassim, M.H., \& Azila, N.M.A. (2004). A first attempt at problema based learning in process dynamics and control course for chemical engineering undergraduates at Universiti Teknologi Malaysia. 5th Asia Pacific Conference on Problem-based Learning. Petaling Jaya.

Mohd-Yusof, K., Sadikin, A.N., Phang, F.A., \& Abdul-Aziz, A. (2016). Instilling professional skills and sustainable development among first year engineering students. International Journal of Engineering Education, 32(1), 333-347.

Moreira, F., Mesquita, D., \& Hattum-Janssen, N.V. (2011). The importance of the Project theme in project-based learning: A study of student and teacher perceptions. Paper presented at the International Symposium on Project Approaches in Engineering Education (PAEE'2011). Aligning Engineering Education with Engineering Challenges. Lisbon, Portugal.

Morss, A., \& Billiar, K. (2016). Problem-Based Learning in Biomechanics: Advantages, Challenges, and Implementation Strategies. Journal of Biomechanical Engineering, 138(7). https://doi.org/10.1115/1.4033584

Nordin, N.M., \& Subramaniam, T.S. (2013). Problem Based Learning Approach in the Designing of E-content for Engineering Courses. Asian Social Science, 9(10), 300-306.

https://doi.org/10.5539/ass.v9n10p300

Okyere, G.A., Tawiah, R., Lamptey, R.B., Oduro, W., \& Thompson, M., (2017). An assessment of resource availability for problem based learning in a Ghanaian University setting. Quality Assurance in Education, 25(2). https://doi.org/10.1108/QAE-12-2015-0046

Othman, H., Mat-Daud, K.A, Ewon, U., Mohd-Salleh, B., Omar, N.H., Abd-Baser, J. et al. (2017). Engineering Students: Enhancing Employability Skills through PBL. IOP Conf. Series: Materials Science and Engineering. https://doi.org/10.1088/1757-899X/203/1/012024

París-Mañas, G., Mas-Torelló, O., \& Torrelles-Nadal, C. (2016). La evaluación de la competencia "trabajo en equipo" de los estudiantes universitarios. RIDU Revista d'Innovació Docent Universitària, 8, 86-97. Available at: http://revistes.ub.edu/index.php/RIDU 
Passow, H.J. (2012). Which ABET Competencies Do Engineering Graduates Find Most Important in Their Work? Journal of Engineering Education, 101(1), 95-118. https://doi.org/10.1002/j.2168-9830.2012.tb00043.x

Polanco, R., Calderón, P., \& Delgado, F. (2004). Effects of a problem-based learning program on engineering students' academic achievements in a mexican university. Innovations in Education and Teaching International, 41(2), 145-155. https://doi.org/10.1080/1470329042000208675

Prince, M., \& Felder, R. (2006). Inductive teaching and learning methods: Definitions, comparisons, and research bases. Journal of Engineering Education, 95(2), 123-138. https://doi.org/10.1002/j.21689830.2006.tb00884.x

Pyle, E. \& Hung, W. (2019). The role of subject presence type on student motivation in a PBL learning environment. Advances in Health Sciences Education. https://doi.org/10.1007/s10459-019-09889-2

Rinaudo, M.C., \& Donolo, D. (2010). Estudios de diseño. Una perspectiva promisoria en la investigación educativa. RED - Revista de Educación a Distancia. 22, 1-29.

Robledo, P., Fidalgo, R., Arias, O., \& Álvarez, M.L. (2015). Percepción de los estudiantes sobre el desarrollo de competencias a través de diferentes metodologías activas. Revista de Investigación Educativa, 33(2), 369-383. https://doi.org/10.6018/rie.33.2.201381

Robles-Obando, N. (2013). Eleventh LACCEI Latin American and Caribbean Conference for Engineering and Technology (LACCEI'2013). Innovation in Engineering, Technology and Education for Competitiveness and Prosperity. Cancun, Mexico. Desarrollo de Competencias Genéricas Mediante el Aprendizaje Basado en Problemas.

Rodríguez, C.A. \& Fernández-Batanero, J.M. (2016). A review of Problem-Based Learning applied to Engineering. International Journal on Advances in Education Research, 3 (1), 14-31.

Rodríguez, C.A., \& Fernández-Batanero, J.M. (2017). Evaluación de un Aprendizaje Basado en Problemas en Estudiantes Universitarios de Ingeniería de Riego. Journal of Science Education, 18(2), 90-96.

Rosen, K.H. (2012). Discrete Mathematics and its Applications (7th ed.). McGraw-Hill Companies, NewYork.

Said, S.M., Mahamd-Adikan, F.R., Mekhilef, S., \& Abd-Rahim, N. (2005). Implementation of the problembased learning approach in the Department of Electrical Engineering, University of Malaya. European Journal of Engineering Education, 30, 129-136. https://doi.org/10.1080/03043790512331313895

Savery, J.R. (2015). Overview of problem-based learning: Definitions and distinctions. In Walker, A., Leary, H., Hmelo-Silver, C.E., \& Ertmer, P.A. (Eds.), Essential Readings in Problem-Based Learning: Exploring and Extending the Legacy of Howard S. Barrows (5-15). West Lafayette, IN, USA: Purdue University Press.

Savin-Baden, M. (2007). Challenging Models and Perspectives of Problem-Based Learning. In de Graaff, E., \& Kolmos, A. (Eds.), Management of change; implementation of Problem-Based and Project-Based Learning in engineering (9-29). Rotterdam/Taipei: Sense Publishers. https://doi.org/10.1163/9789087900922_003

Savin-Baden, M. (2014). Problem-based learning: New constellations for the 21st Century. Journal of Excellence in College Teaching, 25(3/4) 197-219.

Schmal, R. (2015). Evolución de un Programa de Formación en Competencias Genéricas. Formación Universitaria, 8(6), 95-106. https://doi.org/10.4067/S0718-50062015000600012

Schmidt, H.G. (1993). Foundations of Problem-Based Learning-Some Explanatory Notes. Medical Education, 27, 422-432. https://doi.org/10.1111/j.1365-2923.1993.tb00296.x

Torrelles, C. (2011). Eina d'avaluació de la competència de treball en equip. Tesis doctoral.

Torrelles, C., París, G., Sabrià, B., \& Alsinet, C. (2015). Assessing teamwork competence. Psicothema, 27(4), 354-361. 
Wang, J., \& Fong, Y. C. (2006, July). Leveraging on simulation to enhance problem-based learning in engineering. Paper presented at International Conference PBL 2006 ABP, Peru.

Warnock, J.N., \& Mohammadi-Aragh, M.J. (2015). Case study: use of problem-based learning to develop students' technical and professional skills. European Journal of Engineering Education.

https://doi.org/10.1080/03043797.2015.1040739

Yadav, A., Subedi, D., Lundeberg, M.A., \& Bunting, C.F. (2011). Problem-based Learning: Influence on Students' Learning in an Electrical Engineering Course. Journal of Engineering Education, 100(2), 253-280. https://doi.org/10.1002/j.2168-9830.2011.tb00013.x

Yarosh, M., Serbati, A., \& Seery, A. (Ed.) (2017). Developing generic competences outside the university classroom. Granada, España: Universidad de Granada. Campus Universitario de Cartuja.

Yew, E.H.J., \& Goh, K. (2016). Problem-Based Learning: An Overview of its Process and Impact on Learning. Health Professions Education. https://doi.org/10.1016/j.hpe.2016.01.004

Yew, E.H., \& O'Grady, G. (2012). One-day, one-problem at republic polytechnic. In O'Grady, G., Yew, E.H.J., Goh, K.P.L., \& Schmidt, H.G. (Eds.), One-day, one-problem (3-19). New York, NY: Springer. https://doi.org/10.1007/978-981-4021-75-3

Yih-Chyn A, M. \& Huijser, H. (2017). Problem-based Learning into the Future. Imagining an Agile PBL Ecology for Learning. Springer, Science+Business Media Singapore. https://doi.org/10.1007/978-981-10-2454-2

Published by OmniaScience (www.omniascience.com)

Journal of Technology and Science Education, 2020 (www.jotse.org)

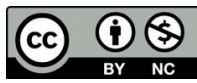

Article's contents are provided on an Attribution-Non Commercial 4.0 Creative commons International License. Readers are allowed to copy, distribute and communicate article's contents, provided the author's and JOTSE journal's names are included. It must not be used for commercial purposes. To see the complete licence contents, please visit https://creativecommons.org/licenses/by-nc/4.0/. 